Agro-Science Journal of Tropical Agriculture, Food, Environment and Extension Volume 19 Number 2 (Apr. 2020) pp. $36-40$

ISSN 1119-7455

\title{
AN ASSESSMENT OF AQUACULTURE TABLE-SIZE FISH FARMERS ACTIVITIES IN KAINJI LAKE BASIN, NIGERIA
}

\author{
*Omeje J.E., Sule A.M. and Aguihe E.O. \\ Division of Socio-Economic \& Extension Services, \\ National Institute for Freshwater Fisheries Research, New Bussa, Niger State, Nigeria \\ *Corresponding author's email: juliusomeje@ gmail.com
}

\begin{abstract}
The study assessed aquaculture table-size fish farmer's activities in the Kainji Lake basin, Nigeria. Specifically, the study examined aquaculture activities in the area, assessed market information, channels and support organizations, and identified the major constraints to aquaculture table-size fish farming in the area. A two-stage sampling technique was used to select 120 table-size fish farmers. Primary data were collected with a questionnaire and presented using descriptive statistics. The result shows that majority of the respondents were males (82.1\%), with mean age of 36.7 years, $53.8 \%$ had tertiary educational qualification while $66.7 \%$ had more than six years' experience in fish farming. Majority (92\%) of the table-size fish farmers operate with less than two ponds, $51 \%$ practice earthen pond system, while $91 \%$ of the farmers engage in the business for the purpose of generating income. Majority (90\%) of the farmers sell their farmed fish after six months, $80 \%$ of the sales take place at farm-gate level, $80 \%$ of the owners of the fish farms are contacted directly by fish buyers. Also, majority (53.8\%) of the fish buyers are the middle men who buy and resell to other fish users (processors, consumers, farmers etc). The major constraints to table-size fish farming were inadequate capital (46.2\%), poor water management (33.3\%), high cost of feed (10.3\%) and poor pricing (10.3\%). It is therefore recommended that fish farmers should form strong Farmer Associations to enable them combat the issues of accessing capital and poor pricing. This will aid in business expansion as the farmers will take advantage of economy of scale.
\end{abstract}

Key words: aquaculture, table-size, fish, farmers

\section{INTRODUCTION}

Aquaculture refers to the culture/rearing of aquatic organisms such as shell fish (Shrimps, Prawns), fin fish, crustaceans (aquatic snails), amphibians (toads, frogs, etc.) and aquatic plants (Madu, 2016). The development of the aquaculture sector became necessary as a result of the increased pressure on the globally available fisheries stocks (due to noxious fishing methods) and the growing human population which became clear that the capture fisheries have either reached their upper limit or near collapse (Committee for Inland Fisheries and Aquaculture of Africa, CIFAA, 2017). Aquaculture is the fastest growing sector of the world food economy, increasing by more than $10 \%$ per year and currently accounts for more than $30 \%$ of all fish consumed (Sea Web, 2004). However, since 2000 , world aquaculture no longer enjoys the high annual growth rates of the 1980s and 1990s (10.8 and $9.5 \%$, respectively). Nevertheless, aquaculture continues to grow faster than other major food production sectors (FAO, 2016). Even though annual growth declined to a moderate $5.8 \%$ during 2001-2016, double-digit growth still occurred in a small number of individual countries, particularly in Africa from 2006 to 2010 (FAO, 2016).
Aquaculture in Nigeria started in Panyam fish farm, Jos in 1951, as a government-driven venture which has now spread to all parts of the federation as a private sector-driven affair (Akinrotimi et al., 2011). The focus of aquaculture in Nigeria is on fish culture with Clarias and Heterobranchus spp. (catfish), Tilapia spp. (Tilapia), Cyprinus carpio (Common carp), Heterotis niloticus (Slap water) the most commonly cultured species of fish (Olagunju et al., 2007; Adewumi, 2015). These species that are cultured usually grow to a minimum acceptable marketable size in a reasonable growing period (between 4 and 9 months) depending on the production system (Adewumi, 2015). However, among the four species highlighted, most table-size fish farmers culture catfish not only because it adapts well to culture environment and can easily be retailed live, but also because it attracts premium price (Asa and Obinaju, 2014).

Aquaculture in Nigeria suffers from several setbacks arising from; poor extension services, lot of skill gaps between the managerial supervisory unskilled personnel, lack of fishermen's cooperative societies, poor infrastructural facilities, scarcity of quality seeds (fingerlings), high cost of feeds, high cost of transportation, water problem, 
inadequate capital, poor adoption of modern technologies, poor storage facilities, mortality of fish due to diseases and water pollution and poaching (Ugwumba, 2005; Adeogun et al., 2007; Osawe, 2007; Ugwumba and Orji, 2007; Ugwumba and Nnabuife, 2008). All these issues can discourage farmers from active engagement in aquaculture, also, insufficient information on aquaculture table-size (grow-out) fish farmers activities in the study area necessitated this study, hence; the objectives of the study were to; (i) examine the level of aquaculture activities in the area, (ii) assess market information, channels and support organizations, and (iii) identify the major constraints to aquaculture in the area.

\section{MATERIALS AND METHODS}

The study was carried out in Kainji Lake Basin, Nigeria. The lake, formed in 1968 as an impoundment of River Niger, is situated between Latitudes $9^{\circ} 50^{\prime}$ North and longitudes $4^{\circ} 40^{\prime}$ East (Salami et al., 2015). It has a total area of $1270 \mathrm{~km}^{2}$ (Mayomi and Olokor, 2014) with length of $136 \mathrm{~km}$, width of $24 \mathrm{~km}$, maximum head elevation of $141.73 \mathrm{~m}$ and maximum tail elevation of $104 \mathrm{~m}$ (Salami et al., 2015). The major occupation of the inhabitants of the Kainji Lake area is crop farming whereas fishing, trading and other informal sector activities provides source of livelihood to others (Umar and Illo, 2014). Kainji Lake comprises about 316 fishing communities demarcated into three strata; upper stratum (northern basin), middle stratum (central basin) and lower stratum (southern basin).

A two-stage sampling technique was adopted in this study. In the first stage, 20 fishing communities were purposively selected based on preponderance of aquaculture fish farmers. The communities were Yauri, Rofia, Mahuta, Kokoli, Zamare, Utonu from the upper stratum; Duga, Mashaya, T. Gungawa, Gafara, Wawu, wara, Shagunu from the middle stratum, and New bussa, Monai, T. A. Danbaba, Musawa, Malale, T/Na'ilo, Cover Dam from the lower stratum. In the second stage, 6 table-size fish farmers were randomly selected in each of the communities previously selected making a total 120 fish farmers selected from a population 229 table-size fish farmers in the strata. Data were collected with a questionnaire and presented using descriptive statistics such as frequency, percentage, mean, pie chart, bar chart and line graph.

\section{RESULTS AND DISCUSSION}

\section{Socio-Economic Characteristics of Fish Farmers}

The result of the socio-economic characteristics (Table 1) shows that there is higher number of males $(82.1 \%)$ than females $(17.9 \%)$ table-size fish farmers. This corresponds to the findings of Ukpe et al. (2017) who reported that majority of catfish farmers were males. The low representation of females in this enterprise could be as a result of the

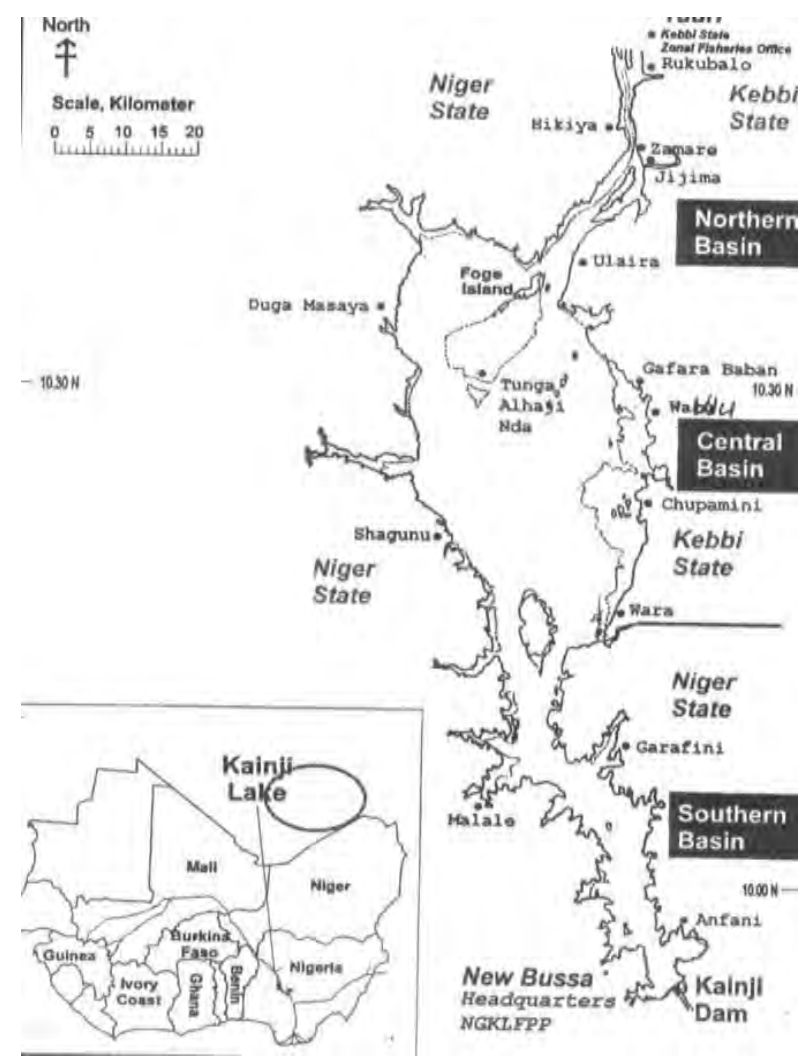

Figure 1: Map of kainji lake basin Source: Raji et al. (2011)

labour-intensive nature of fish farming such as; pond digging, fish harvesting, sampling and the like, which requires one with a masculine disposition to carry out. The majority $(76.1 \%)$ are within the age category of 31-40 years with mean age of 36.7 years. The result corresponds to the findings of Akarue and Aregbor (2015) and Oluwasola and Ige (2015) who reported similar results from data collected in Delta and Oyo states respectively. This shows that the majority of the fish farmers are still within the economically active age. This indicates that the aquaculture business in the area is being dominated by young men and women. Also, it indicates that the business is in the hands of those who possess the potentials to expand for higher income.

Table 1: Socio-economic characteristics of fish farmers

\begin{tabular}{|c|c|c|c|}
\hline \multirow{3}{*}{ Sex } & Variables & Percent & Mean \pm SD \\
\hline & Male & 82.1 & \\
\hline & Female & 17.9 & \\
\hline \multirow{2}{*}{$\begin{array}{l}\text { Age } \\
\text { (years) }\end{array}$} & $21-30$ & 12.8 & \\
\hline & $31-40$ & 76.1 & \\
\hline \multirow{6}{*}{$\begin{array}{l}\text { Level of } \\
\text { education }\end{array}$} & $41-50$ & 5.1 & \\
\hline & 51 and above & 6.0 & $36.7 \pm 5.84$ \\
\hline & Primary & 28.2 & \\
\hline & Secondary & 5.1 & \\
\hline & Tertiary & 53.8 & \\
\hline & No formal education & 12.9 & \\
\hline \multirow{4}{*}{$\begin{array}{l}\text { Years of } \\
\text { experience }\end{array}$} & Education & & \\
\hline & $1-3$ & 17.9 & \\
\hline & $4-6$ & 15.4 & \\
\hline & $>6$ & 66.7 & $3.43 \pm 1.36$ \\
\hline
\end{tabular}

Source: Field Survey, 2018 
Furthermore, the level of education shows that the aquaculture table-size fish farmers have good level of education as the majority $(53.8 \%)$ have attained tertiary level of education. Also, the year of experience of farmers is quite encouraging as the majority (66.7\%) has been in the business for over six years. This is in consonance with the result of Asa and Obinaju (2014) who reported that catfish farmers in Akwa Ibom State, Nigeria had experience in fish farming for up to six years. Also, a good number of years of experience show how fish farmers were able to manage and sustain their businesses which is an important factor determining both the productivity and the production level in farming (Ololade and Olagunju, 2013).

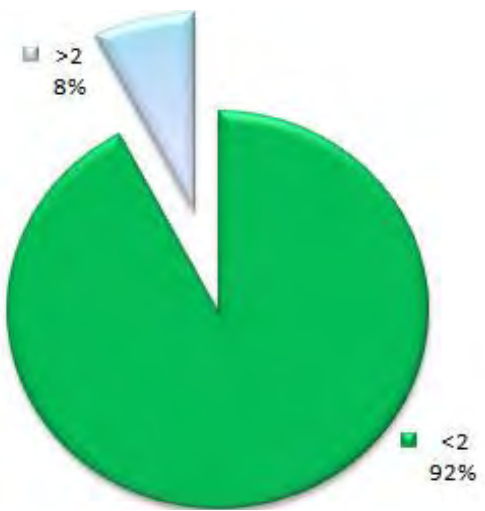

Figure 2: Number of ponds

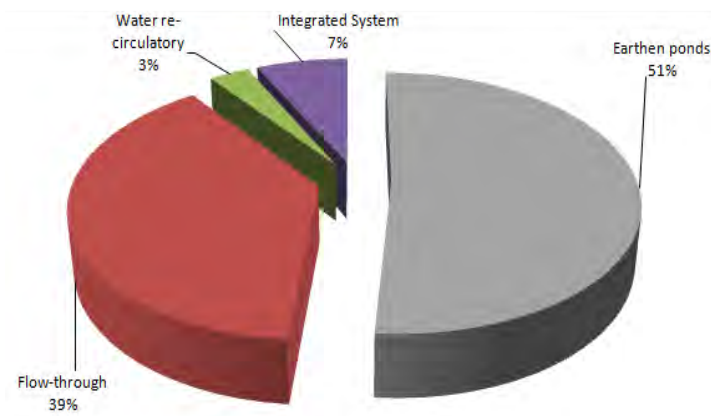

Figure 3: Production system

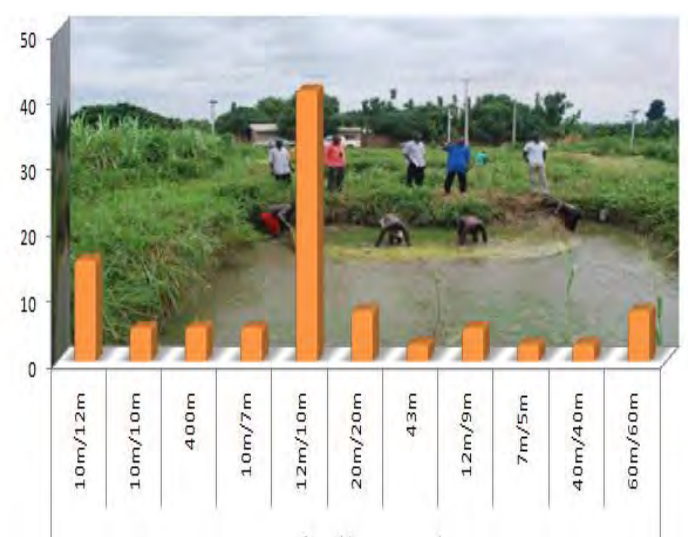

Figure 4: Size of pond (square-meter)

\section{Assessment of Aquaculture Activities}

The results in Figures 2-7 show that majority (92\%) of the table-size fish farmers operate with very low number of ponds $(<2)$ with pond sizes of $12 \mathrm{~m} / 10 \mathrm{~m}$. Majority $(51 \%)$ practice earthen pond system even though flow-through system is gaining prominence. This result corresponds to the report by Partnership Initiatives in the Niger-Delta [PIND] (2011) which indicates that in the Niger Delta region, small scale farmers overwhelmingly adopt the practice of green-water/earthen pond system compared to the flow through system mostly operated by large scale farmers. Most of the farmers $(50 \%)$ own the land used for fish farming while a reasonable number of farmers $(45 \%)$ rent their farm lands.

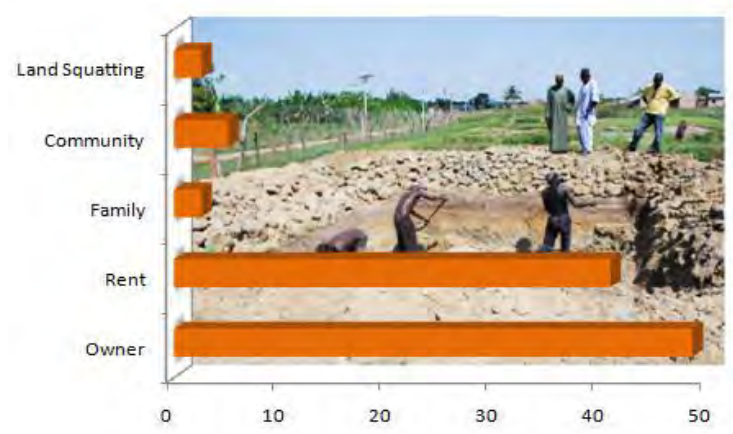

Figure 5: Access to land

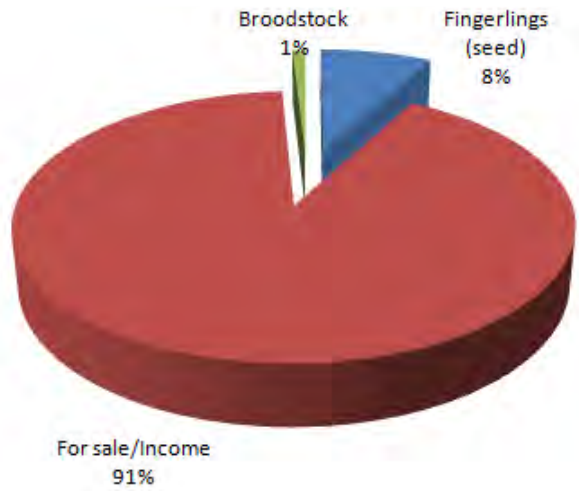

Figure 6: Purpose for fish farming

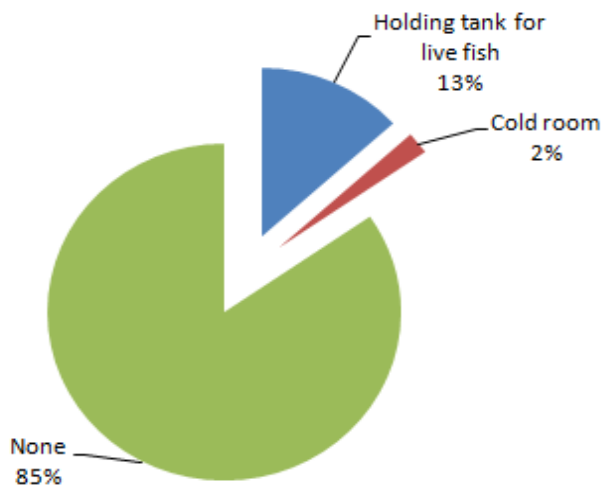

Figure 7: Post-harvest storage facilities

Source: Field survey, 2018 
Furthermore, the findings show that majority $(91 \%)$ of the farmers engage in the business for the purpose of generating income as table size fish farming is perceived to be more lucrative than other value chain activities (Ifejika et al., 2015). However, the inability of the fish farmers to acquire or use certified post-harvest storage facilities portends a low capacity of infrastructure used in fish farming as observed with respect to the number of ponds used for fish farming.

\section{Market Information, Channels and Support Organizations}

The results on market information shows that fish farmers operate within an imperfect market structure as most sales take place at farm gate level $(80 \%)$ with the owners $(80 \%)$ as the main contact persons. This shows how weak "Farmer Associations" perform in enhancing fish prices since most of the farmers transact directly with middlemen or buyers thereby placing the farmers at a disadvantage. Also, majority $(90 \%)$ of the farmers sell their farmed fish after six months as a minimum production cycle for table-size fish. Fish species that are cultured for 4-9 months usually grow to a minimum acceptable marketable size depending on the production system (Adewumi, 2015). The findings further show that the main buyers were middlemen $(53.8 \%)$ who buy and resell to others (processors, consumers, farmers, etc). These middlemen (wholesalers and retailers) add value to the aquaculture business by ensuring that fish is available at the place and time required by processors and consumers (Madugu and Edward, 2011; Umoinyang, 2014).

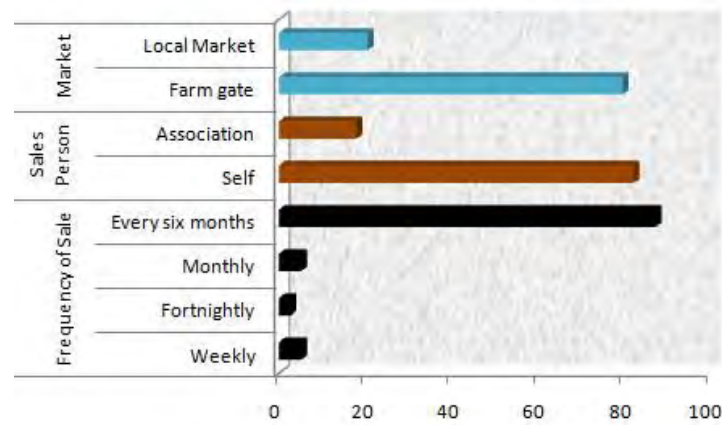

Figure 8: Market information (Source: Field Survey, 2018)

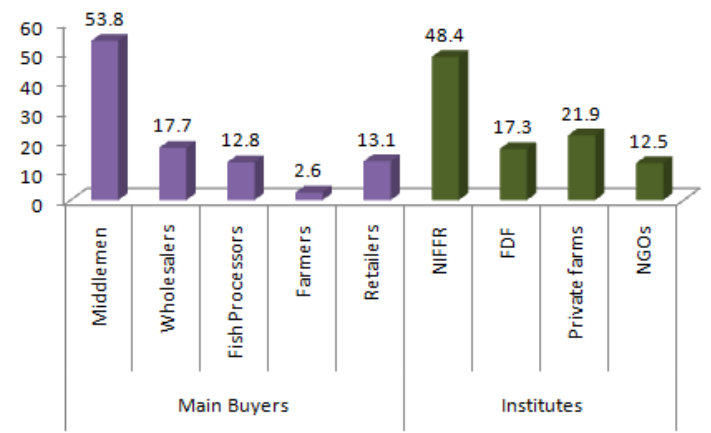

Figure 9: Channels and support organizations
In addition to these, the farmers indicate that National Institute for Freshwater Fisheries Research (NIFFR) is the institution which has close proximity to them in terms of technical support in their farm operations. This is in line with the mandate of the Institute (Raji et al., 2011), as most farmers indicate that technical know-how, technology, inputs and market intelligence were the most assistance/support received from the institute. This is also shown in the report of PIND (2011) who reported that Nigeria's fisheries sector has had support and technical assistance from series of donors, NGOs and government agencies in which NIFFR is one of those organizations. However, the periods in which such supports were received from the institute were on occasional bases which are issues of serious concern. Subsidies and credit were least indicating the weakness of the fish farmers to form functional cooperatives to assist themselves.

\section{Constraints to Fish Farming}

The analysis shows that inadequate capital (46.2\%) was the most serious constraint to fish farming and possibly expansion. The importance of capital to fish farming cannot be overemphasized. Capital is needed to purchase land, feed, construct ponds, buy drugs etc. hence, capital is considered sine qua non to fish farming. This result agrees with Asa and Olagunju (2014). In addition, the farmers indicate poor water management $(33.3 \%)$, high cost of feed $(10.3 \%)$ and poor pricing $(10.3 \%)$ as the major constraints to fish farming. Similar results have been reported by researchers (Agboola, 2011; Akarue and Aregbor, 2015; Ogunmefun and Achike, 2017).

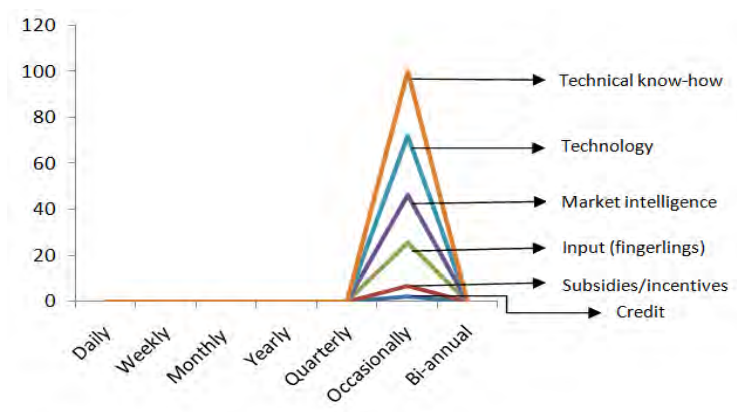

Figure 10: Kinds of support received (Source: Field Survey, 2018)

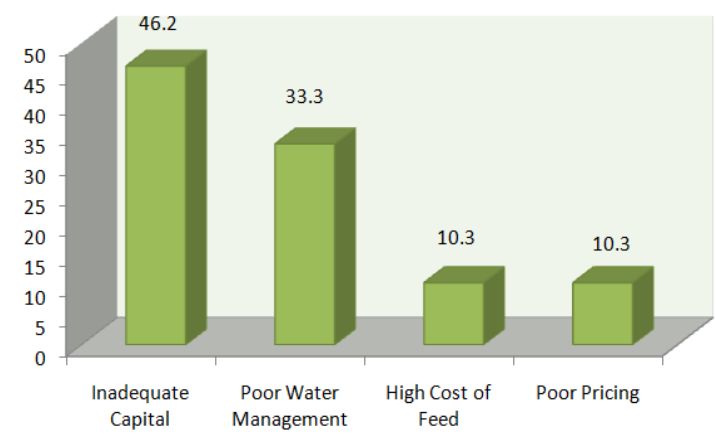

Figure 11: Constraints to fish farming Source: Field Survey, 2018 


\section{CONCLUSION}

The study found that aquaculture table-size fish farmers were within their economically active age; have good educational qualification with a reasonable number of years of experience in fish farming. However, these fish farmers have small number of ponds which are mostly earthen ponds situated on their own lands. The farmers indicated that their primary objective of fish farming was to generate income; however, they showed very low usage of storage facilities which could hamper their profit level in the business. Furthermore, the study revealed that farmers operate within an imperfect market structure as most sales take place at farmgate level, with the owners being the main contact person indicating weakness in the formation of "Farmer Associations" in the region. The farmers indicated that National Institute for Freshwater Fisheries Research (NIFFR) provides them with technical support which is in line with the mandate of the Institute. The major constraints to table-size fish farming were lack of capital, poor water management, high cost of feed and poor pricing. It is recommended that table-size fish farmers in the region should form "Farmer Associations" to enable them take advantage of economy of scale, as their age and educational level can be a source of strength in enterprise management and possibly expansion.

\section{REFERENCES}

Adeogun O.A., Ogunbadejo H.K., Ayinla O.A., Oresegun A., Oguntade O.R., Tanko A. and William S.B. (2007). Urban aquaculture: producer perceptions and practice in Lagos State, Nigeria. Middle-East J. Sci. Res., 2, 21-27

Adewumi A.A. (2015). Aquaculture in Nigeria: sustainability issues and challenges. Direct Res. J. Agric. Food Sci., 3 (12), 223-231

Agboola W.L. (2011). Improving fish farming productivity towards achieving food security in Osun State, Nigeria: a socioeconomic analysis. Annals Biol. Res., 2 (3), 62-74

Akarue O.B. and Aregbor O.E. (2015). Socio- economic analysis of catfish farming in Uvwie Local Government Area, of Delta State, Nigeria. Int. J. Innovative Agric. Biol. Res., 3 (3), 33-43

Akinrotimi O.A., Abu O.M.G. and Aranyo A.A. (2011). Environmental friendly aquaculture: key to sustainable fish farming development in Nigeria. Continental $J$. Fisheries Aquatic Sci., 5 (2), 17-31

Asa U.A. and Obinaju L.C. (2014). Economics of catfish production in Akwa Ibom State, Nigeria. Global J. Manage. Bus. Res.: B Econs. Commerce, 14 (3), 23-28

Committee for Inland Fisheries and Aquaculture of Africa [CIFAA]. (2017). Status of inland fisheries and aquaculture in Africa (C IFAA/XVII/2017/4). Banjul, Gambia. Retrieved from http://www.fao.org/fi/staticmedia/MeetingDocuments/CIFAA/CIFAA17/4e.pdf

FAO (2016). The State of World Fisheries and Aquaculture Report. Food and Agriculture Organization (FAO), Rome. Retrieved from http://www.fao.org/3/9540en//9540EN.pdf

Ifejika P.I., Asadu A.N., Enwelu I.A., Sanni A.O., Nwabeze G.O. and Omeje J. (2015). Determining youth choice of enterprise in aquaculture production for job creation in Abia State, Nigeria. Nigerian J. Fisheries, 12 (1), 809-914
Madu C.T. (2016). Introducing fish farming/ aquaculture and the entrepreneurial opportunities-an overview. In Madu C.T. (Ed.), Fish Farming: The Value Chain Approach (1st ed.), Palmgrove: Lagos, Nigeria: In Him Resources Ltd, 1-2

Madugu A.J. and Edward A. (2011). Marketing and distribution channel of processed fish in Adamawa State, Nigeria. Global J. Manage. Bus. Res., 11(4), 21-26

Mayomi, I. andOlokor, J. O. (2014). Monitoring the land-use and vegetation cover changes in the Kainji Lake Basin, Nigeria (1975-2006). African Journal of Environmental Science and Technology,8 (2), 129-142

Ogunmefun S.O. and Achike A.I. (2017). Socioeconomic characteristics and constraints of pond fish farmers in Lagos State, Nigeria. Agric. Sci. Res. J., 7 (10), 304-317

Olagunju F.I., Adesiyan I.O. and Ezekiel A.A. (2007). Economic viability of catfish production in Oyo State, Nigeria. J. Human Ecol., 22 (12), 121-124

Ololade R.A. and Olagunju F.I. (2013). Determinants of access to credit among rural farmers in Oyo State, Nigeria. Global J. Sci. Frontier Res., Agric. Vet. Sci., 13 (2), 16-22

Oluwasola O. and Ige A.O. (2015). Factors determining the profitability of catfish production in Ibadan, Oyo State, Nigeria. Sustainable Agric. Res., 4 (4), 57-65

Osawe M. (2007). Technical know-how of catfish growout for table size in 4-6 months. Proc. Seminar on Modern Fish Farming by Dynamo Catfish Production, Lagos, Nigeria, 1-14

Partnership Initiatives in the Niger-Delta [PIND]. (2011). A report on aquaculture value chain analysis in the Niger Delta. Retrieved from http://www.ndpifoundation.org/ images/researchreports/reports/Aquaculture-Value-Chain-Analysis.pdf

Raji A., Okaeme A.N. and Ibeun M. (2011). Forty Years on Lake Kainji Fisheries Research (p. 4). New Bussa, Niger State: Natl. Inst. for Freshwater Fisheries Res. Press

Salami A.W., Mohammed A.A., Adeyemo J.A. and Olanlokun O.K. (2015). Evaluation of climate change impact on runoff in the Kainji Lake Basin using artificial neural network model. Int. J. Water Resour. Environ. Engineering, 7 (2), 7-16

Sea Web (2004). At a Crossroads: Will Aquaculture Fulfill the Promise of the Blue Revolution? A SeaWeb Aquaculture Clearinghouse report by Kathryn White, Brendan O'Neill and Zdravka Tzankova

Ugwumba C.O.A. (2005). The economics of homestead concrete fish pond in Anambra State, Nigeria. Afr. J. Fisheries Aquaculture, 4, 28-32

Ugwumba C.O.A. and Nnabuife E.L.C. (2008). Comparative study on the utilization of commercial feed and home-made feed in catfish production for sustainable aquaculture. Multidiscipl. J. Res. Dev., 10, 164-169

Ugwumba C.O.A. and Orji E.C. (2007). Comparative study on financial implications of flow-through and recirculating aquaculture practices in Anambra State, Nigeria. Nigerian J. Res. Productivity, 10, 62-68

Ukpe U.H., Audu N.D., Djomo C.R.F. and Akise O.G. (2017). Economics of catfish farming in selected Local Government Areas of Taraba State, Nigeria. Innovative Techniques Agric., 23, 376-382

Umar S. and Illo A.I. (2014). Performance assessment of artisanal fisheries in the Kainji dam area of Yauri Emirate, Kebbi State Nigeria. Journal of Biology, Agriculture and Healthcare, 2 (20), 18-22

Umoinyang M.E. (2014). Economics of Fish Marketing in Akwa-Ibom State, Nigeria. Department of Agricultural Economics, University of Nigeria, Nsukka. 73 pp. 